\title{
Bioprotection - getting the most out of biological control in pasture pest management
}

\author{
T.A. JACKSON ${ }^{1}$, A.J. POPAY ${ }^{2}$ and S.L. GOLDSON ${ }^{1}$ \\ ${ }^{1}$ Biocontrol and Biosecurity, AgResearch, PO Box 60, Lincoln. \\ ${ }^{2}$ Plant Breeding and Genomics, AgResearch Ruakura, Private Bag 3123, Hamilton \\ trevor.jackson@agresearch.co.nz
}

\begin{abstract}
Pasture damage from insect pests is an increasing concern with rising forage value and biosecurity breaches. At the same time options for traditional chemical control of pests are becoming limited. Biological control of insect pests is important in limiting pest damage, with toxin-producing endophytes, parasitoids and insect diseases the key components limiting insect pest populations and damage in pastures. We are proposing a bioprotection strategy for pasture pest management that maximises the benefit of biocontrol and changes the emphasis from curative to preventative action in the protection of pastures from damaging pests.
\end{abstract}

Keywords: bioprotection, biological control, insect pests, pest management

\section{Introduction}

Increasing animal production through increased efficiency of forage production and utilisation is a major aim of our livestock industries. In exploiting the forage resource we become exposed to insect pest competitors. Competition from pests increases in importance as the value of forage increases and new species are added through biosecurity breaches. Over the past decades we have moved from reliance on chemicals to integrated pest management (IPM) for pest control. IPM is dependent on exploiting a strong base of natural biological control, which has become the dominant form of pest management in our pasture systems, resulting in a drastic reduction in chemical usage. Advances in biocontrol systems and technologies in recent years suggest we can move from considering biocontrol as a curative technology to a protective approach. In this paper we will look at the role of insect-toxin-producing plant endophytes, weevil attacking parasitoids and insect diseases in providing bioprotection against insect pests in our pastures.

\section{The insect pest complex}

New Zealand pastures are dominated by exotic plant species, predominantly white clover (Trifolium repens) and ryegrass (Lolium perenne), covering 11 million ha of productive land. A limited number of endemic insects, such as grass grub and porina, have been able to exploit introduced pasture species and have been reported since the earliest days of pasture improvement (Table 1). Endemic species attacking pastures have been joined by exotic, invasive pests in a steady but growing stream. One example, Argentine stem weevil (ASW) probably arrived from the River Plate region with horse fodder a century ago while clover root weevil (CRW) was first recorded in 1996 (Barratt et al. 1996).

\section{Cost of pest impacts}

The effects of insect pests in pastures can be dramatic and are estimated to cost the pastoral industry more than $\$ 600$ million per annum (Barlow \& Goldson, 2002). Acute effects can be severe. It is not uncommon for new pasture to be severely damaged by grass grub with $>50 \%$ of the sward destroyed in a single autumn. Similarly, ASW-susceptible ryegrasses can be completely eliminated during dry summers leading to poor pasture growth when soil moisture is restored after

Table 1 Major endemic and exotic insect pest species attacking NZ pastures.

\begin{tabular}{|c|c|c|c|}
\hline & Scientific name & Common name & Main areas of concern \\
\hline demic pests & $\begin{array}{l}\text { Costelytra zealandica } \\
\text { Wiseana spp } \\
\text { Odontria spp }\end{array}$ & $\begin{array}{l}\text { Grass grub } \\
\text { Porina } \\
\text { Chafers }\end{array}$ & \multirow{2}{*}{$\begin{array}{l}\text { New Zealand wide } \\
\text { Lower North Island; South Island } \\
\text { South Island } \\
\text { Extensive pastures - sporadic } \\
\text { East coast South Island - sporadic } \\
\text { New Zealand wide }\end{array}$} \\
\hline kotic pests & $\begin{array}{l}\text { Balanococcus poae } \\
\text { Listronotus bonariensis }\end{array}$ & $\begin{array}{l}\text { Pasture mealy bug } \\
\text { Argentine stem weevil }\end{array}$ & \\
\hline & $\begin{array}{l}\text { Sitona lepidus } \\
\text { Heteronychus arator } \\
\text { Acrossidius tasmaniae } \\
\text { Sitona discoideus } \\
\text { Sminthurus viridus } \\
\text { Graphognathus leucoloma }\end{array}$ & $\begin{array}{l}\text { Clover root weevil } \\
\text { Black beetle } \\
\text { Tasmanian grass grub } \\
\text { Lucerne weevil } \\
\text { Clover flea } \\
\text { White fringed weevil }\end{array}$ & $\begin{array}{l}\text { Northern North Island - spreading } \\
\text { Northern North Island } \\
\text { Both Islands, east coast - sporadic } \\
\text { Dry areas esp. South Island } \\
\text { Northern North Island } \\
\text { North Island }\end{array}$ \\
\hline
\end{tabular}


autumn rains. The subtle, chronic effects of pests however are much more difficult to measure. Grass grub will selectively remove clovers and palatable ryegrass from the sward. Clover root weevil can cause severe damage to clover roots and shoots leading to loss of forage quality and reduction in nitrogen fixation. Conversely, ASW can lead to unwanted clover dominance in pastures.

\section{The costs of control}

The low cost of chemical control in relation to product prices in the 1950s led to widespread adoption of organochlorine-based pesticides such as DDT. After the use of these cheap but problematical pesticides was discontinued, low cost pest control strategies based on IPM that emphasised minimal pesticide use were adopted and served the pastoral industry well from the mid 1970s until the 1990s. More recently, however, as product prices have increased, the value of pasture has increased and with it the demand for an assured supply of quality pasture. At the same time, consumer demand is now forcing a rethink of chemical use altogether. These circumstances are presenting completely new challenges for pasture pest management and have stimulated the development of a novel approach leading to the concept of 'bioprotection'.

\section{The components of bioprotection}

Devastating attacks by pasture pests tend to be sporadic and rare, and it is more common to see productive pastures with relatively low numbers of insects. Pest populations are frequently held in check by factors such as natural enemies, plant resistance and climatic conditions. The natural controls are components of bioprotection and some of those applicable to pasture pest management are presented in Table 2 .

One of the greatest successes in insect control in New Zealand pastures has been through the distribution of fungal endophytes in ryegrass. There is no doubt that bioprotection of ryegrass through use of endophytes improves plant productivity and persistence (Popay et al. 1999) and, in many areas, endophyte-free ryegrasses cannot persist due to feeding damage by ASW and other insect species. However, an undesired side effect of endophytes has been a cost in loss of stock productivity. Selected endophytes, however, have the potential to maximise the biological benefit in insect control without detrimental effects on stock. As an example, the recently released AR1 endophyte protects its ryegrass host from ASW and gives marked improvement in animal performance compared with wild-type endophyte (Fletcher 1999). AR1 also provides protection against pasture mealy bug, but only partial protection against black beetle (Popay et al. 2001). Research on endophytes indicates that there are a wide range of endophytic toxins with potential use in protection of forage species and is focussing on ways to improve plant resistance and extend it to other pasture pests. For example, both porina and grass grub are deterred from feeding by loline alkaloids (Popay \& Lane 2001) which are produced by $N$. coenophialum endophytes in tall fescue. Our challenge for the future will be to utilise this resistance effectively, to protect not only tall fescue but also ryegrass from these pests.

Table 2 Some components of bioprotection for limiting pest damage to pastures.

\begin{tabular}{|c|c|c|}
\hline Organism & Characteristics & Effect \\
\hline Neotyphodium lolii & Endophytic fungus of ryegrass & $\begin{array}{l}\text { Reduces ASW adult feeding and } \\
\text { oviposition and larval damage; deters } \\
\text { black beetle adult feeding and } \\
\text { oviposition; reduces pasture mealy } \\
\text { bug populations }\end{array}$ \\
\hline $\begin{array}{l}\text { Neotyphodium } \\
\text { coenophialum }\end{array}$ & Endophytic fungus of tall fescue & $\begin{array}{l}\text { Reduces insect feeding by a range } \\
\text { of pests }\end{array}$ \\
\hline Microctonus hyperodae & Parasitoid of ASW & $\begin{array}{l}\text { Significantly reduces ASW populations } \\
\text { and damage from larvae }\end{array}$ \\
\hline Microctonus aethiopoides & Parasitoid of the lucerne weevil & $\begin{array}{l}\text { Greatly reduces weevil impacts on } \\
\text { lucerne production }\end{array}$ \\
\hline $\begin{array}{l}\text { Serratia entomophila } \\
\text { S. proteamaculans }\end{array}$ & $\begin{array}{l}\text { Bacteria causing amber disease in } \\
\text { grass grub }\end{array}$ & Grass grub population suppression \\
\hline Wiseana NPV & Virus of porina & Porina population suppression \\
\hline Bacillus popilliae & Milky disease in scarabs & $\begin{array}{l}\text { Grass grub population collapse and } \\
\text { suppression }\end{array}$ \\
\hline Metarhizium anisopliae & Fungal disease of porina and grass grub & $\begin{array}{l}\text { Reduced flights due to high levels of } \\
\text { infection in late instar larvae }\end{array}$ \\
\hline Beauveria bassiana & Fungal disease of ASW & Autumn population suppression \\
\hline
\end{tabular}


In the 1970s the lucerne weevil invaded New Zealand. This species' root nodule-feeding habit and its propensity to defoliate the lucerne crops contributed to the sharp erosion in confidence in this crop through the 1980s. However, such decline in interest may have been premature inasmuch as the weevil was effectively suppressed by an introduced parasitoid (Microctonus aethiopoides) (Barlow \& Goldson 1993). This successful suppression, combined with cultivar selections for resistance against aphid pests, means that lucerne may again have a specific role in forage production, particularly in dry east coast areas where, with intensification of land use, there is increasing demand for conserved feed. The lessons learned from this success in lucerne raised the possibility of using another species of Microctonus, from South America, to suppress ASW in pasture. Accordingly, in the 1990s the parasitoid wasp Microctonus hyperodae was introduced (Goldson et al. 1993) and populations of the wasp built up very rapidly in most areas of New Zealand (Goldson et al. 1998a) delivering an appreciable impact against ASW (Goldson et al. 1998b). In 1996, a new and serious pest of clover, the clover root weevil was discovered in New Zealand (Barratt et al. 1996)). Like the lucerne weevil, this species feeds on the clover root nodules and foliage and, within the invasion zone, populations have built up to a level that poses a significant threat to clover-based pasture production. While currently restricted to the northern half of the North Island, it is expected to spread throughout New Zealand. A major search for suitable biological control agents was conducted throughout Europe and a potentially useful parasitoid has been imported into quarantine for further evaluation (Goldson et al. 2001).

Just as parasitoids offer opportunities to permanently reduce pest status, so does disease. Pasture pests can be infected by a wide range of disease-causing microorganisms. Grass grub alone is susceptible to at least 20 known pathogens (Jackson \& Glare 1992). Generally, the level of disease increases in dense populations but there is often a lag effect with high levels of disease occurring only after high populations of pests have caused considerable pasture damage. To exploit the potential of diseases in pasture pest management we need to ensure that high numbers of insect disease causing microbes are present in the pasture soil before the population builds up. This can be achieved by reducing soil disturbance or by addition of pathogens. Minimum tillage practices in pasture renovation help to conserve beneficial microbes whereas cultivation can lead to a resurgence of pests through disruption of the soil microbial community. Where they are lacking, beneficial microbes can be added to restore the protective capability of the soil. Serratia entomophila, the bacteria causing amber disease in grass grub, can be introduced into grass grub populations as the biocontrol product Invade ${ }^{\circledR}$. Application of Invade starts a cycle of disease in the treated grass grub population, usually resulting in a 40-50\% population reduction in the season of application, followed by ongoing cycling and continuing suppression of the grass grub population (Jackson et al. 1992). Fungal diseases are currently under investigation for use in a similar manner against CRW (Willoughby et al. 1998). Many microbes are sensitive to environmental conditions and require special handling but these limitations may be overcome with the development of stable granular formulations of microbes (Johnson et al. 2001).

\section{Effective use of bioprotection in pasture pest management}

Bioprotection is a strategy to make full use of the biological factors that provide protection to our pastures from pests and diseases. It is a multi-tiered approach where the first level of defence is induced resistance of pasture plant species through the presence of endophytic microbes producing insect specific toxins within the plant tissue. Bioprotection also acts at a national level by release and encouragement of parasitoids to bring about general pest suppression of key species. Bioprotection can also be targeted at the paddock scale by defining the presence and level of insect natural enemies and introducing new inocula to start a cycle of activity against pest species.

The components of bioprotection in pasture are, in the main, complementary. For example, endophytes and the ASW parasitoids have combined to provide effective suppression of the weevil pest (Goldson et al. 2000). Similarly, insect pathogens such as S. entomophila are specific to the target pest species and have no effect on other beneficial organisms in the pasture.

Bioprotection is based on new understandings of the level of variation in biocontrol agents. New molecular technologies are enabling us to understand the importance of strain variation in insect biocontrol agents and select those most appropriate for specific situations. Biotechnology techniques can also be used, in combination with historical and climatic analyses, to define pastures at risk of pest attack through a lack of natural enemies (eg. Jackson et al. 1997).

In summary, increased knowledge of pest population dynamics has allowed us to recognise the benefits of natural biological control in pasture production. Practical biological skills and new advances in biotechnology now allow us to manage biocontrol in ways that were previously not possible. As other options for pest control become increasingly restricted it is timely to merge our knowledge in pest biology, 
biocontrol and management to develop bioprotection systems that get the most out of biological control in forage pest management.

\section{REFERENCES}

Barlow, N.D.; Goldson, S.L. 1993. A modelling analysis of the successful biological control of Sitona discoideus (Coleoptera: Curculionidae) by Microctonus aethiopoides (Hymenoptera: Braconidae) in New Zealand. Journal of Applied Ecology 30: 165-178.

Barlow N.D.; Goldson S.L. 2002. Alien invertebrates in New Zealand. In Biological Invasions: Economic and Environmental Costs of Alien Plant, Animal and Microbe Species (D. Pimentel, ed.). CRC Press, Florida, USA. In press.

Barratt, B.I.P.; Barker, G.M.; Addison, P.J. 1996. Sitona lepidus (Coleoptera: Curculionidae), a potential clover pest new to New Zealand. New Zealand Entomologist 19: 23-30.

Goldson, S.L.; Proffitt, J.R.; Baird, D.B. 1998a. Establishment and phenology of the parasitoid Microctonus hyperodae Loan in New Zealand. Environmental Entomology 27: 1386-1392.

Goldson, S.L.; Proffitt, J.R; Baird, D.B. 1998b. The bionomics of Listronotus bonariensis (Coleoptera: Curculionidae) in Canterbury, New Zealand. Bulletin of Entomological Research 88: 415-423.

Goldson S.L.; Phillips C.B.; McNeill, M.R.; Proffitt, J.R.; Cane, R.P. 2001. Importation to New Zealand quarantine of a candidate biological control agent of clover root weevil. Proceedings of the New Zealand Plant Protection Conference 54: 147-151.

Goldson, S.L.; Proffitt, J.R.; Fletcher, L.R.; Baird, D.B. 2000. Multitrophic interaction between the ryegrass host plant, Lolium perenne, its endophyte Neotyphodium lolii, the weevil pest Listronotus bonariensis and its parasitoid Microctonus hyperodae Loan. New Zealand Journal of Agricultural Research 43: 227-233.

Goldson S.L.; McNeill, M.R.; Proffitt, J.R.; Barker, G.M.; Addison, P.J.; Barratt, B.I.P.; Ferguson, C.M. 1993. Systematic mass rearing and release of Microctonus hyperodae (Hym.: Braconidae, Euphorinae), a parasitoid of the Argentine stem weevil Listronotus bonariensis (Col.: Curculionidae) and records of its establishment in New Zealand. Entomophaga 38: 527-536.

Jackson. T.A; Glare, T.R. (eds). 1992. Use of Pathogens in Scarab Pest Management. Intercept, Andover, UK. 298 pp.
Jackson, T.A.; Pearson, J.F.; O'Callaghan, M.; Mahanty, H.K.; Willocks, M. 1992. Pathogen to product - development of Serratia entomophila (Enterobacteriacae) as a commercial biological control agent for the New Zealand grass grub (Costelytra zealandica). Pp. 191-198. In: Use of Pathogens in Scarab Pest Management. Eds. Jackson, T.A.; Glare, T.R. Intercept, Andover, UK.

Jackson, T.A.; Townsend, T.R.; Nelson, T.L.; Richards, N.K.; Glare, T.R. 1997. Estimating amber disease in grass grub populations by visual assessment and DNA colony blot analysis. Proceedings of the New Zealand Plant Protection Conference 50: 165-168.

Johnson, V.W.; Pearson, J.F.; Jackson, T.A. 2001. Formulation of Serratia entomophila for grass grub control. Proceedings of the New Zealand Plant Protection Conference 54: 128-135.

Fletcher, L.R. 1999. "Non-toxic" endophytes in ryegrass and their effect on livestock health and production. In: Ryegrass Endophyte: An Essential New Zealand Symbiosis, Grassland Research and Practice Series No. 7: 133-139

Popay, A.J.; Hume, D.E.; Baltus, J.G.; Latch, G.C.M.; Tapper, B.A.; Lyons, T.B.; Cooper, B.M.; Pennell, C.G.; Eerens, J.P.J.; Marshall, S.L. 1999. Field performance of perennial ryegrass (Lolium perenne) infected with toxin-free fungal endophyte (Neotyphodium spp.). In: Ryegrass Endophyte: An Essential New Zealand Symbiosis, Grassland Research and Practice Series No. 7: 113-122.

Popay, A.J.; Baltus, J.G.; Pennell, C.G.L. 2001. Insect resistance in perennial ryegrass infected with toxinfree Neotyphodium endophyte. Pp 187-193. In: Proceedings of the Grassland Conference 2000 - 4th International Neotyphodium/Grass Interactions Symposium. Eds Paul, V.H., Dapprich, P.D. Universitat-Gesamthochschle, Paderborn, Soest, Germany.

Popay, A.J.; Lane, G.A. 2001. The effect of crude extracts containing loline alkaloids on two New Zealand insect pests. Pp 471-475. In: Proceedings of the Grassland Conference 2000 - 4th International Neotyphodium/Grass Interactions Symposium. Eds Paul, V.H., Dapprich, P.D. UniversitatGesamthochschle, Paderborn, Soest, Germany.

Willoughby, B.E.; Glare, T.R.; Kettlewell, F.; Nelson, T.L. 1998. Beauveria bassiana as a potential biocontrol agent against the clover root weevil, Sitona lepidus. Proceedings of the New Zealand Plant Protection Conference 51: 9-15. 